\title{
Integration of Transitivity and Psycho-Analyses to Explore Stream of Consciousness Technique to Portray Victorian Age
}

\author{
Ms. Ayesha Asghar Gill \\ $\mathrm{PhD}$ Scholar \\ Lecturer, University of Agriculture \\ Faisalabad \\ Pakistan \\ Mr. Shahbaz Haider \\ Government College University \\ Faisalabad \\ Pakistan
}

\begin{abstract}
Systemic Functional Linguistics and Lacanian Psychoanalysis theory emphasize the significant role of language in understanding human situations, creating human experiences and social realities (Tayson, 2006, p. 257). This research aims to explorewriter's deft use of language choices to explicate the overarching socio-cultural effect on characters' mental makeup and their interpersonal relationships. For this purpose, the researcher used Critical Discourse Analysis by employing Halliday's Transitivity system of Systemic functional grammar and Lacanian Psychoanalysis theory as a tool to analyze a short story "The Duchess and the Jeweler" by Virginia Woolf. The results found Oliver (main character) as the representative of the morally bankrupt Victorian society, who transgressed ethical order to achieve materialist standard of respectability of his age. For being the representative of morally hollow Victorian age, the writer deployed highest frequency of material processes, projected by paratactic verbal quotes in the discursive narrative style of the writer to present social ails as the locution of the characters and kept herself detached from the straight description of Victorian social scenario. This linguistic functional analysis was further corroborated by psychoanalysis of Virginia's specific technique of narration: Stream of Consciousness, in Lacanion perspective of Imaginary Order and the Symbolic Order of main the character. It endorsed main character selfish motives to meet prevalent age nobility standard. Hence, it is likely to infer that this research has potential to assist English Language Learners to understand the complex linguistic and social semiotic perspective behind the discursive literary text writing style.
\end{abstract}

Keywords: systemic functional grammar, psycho-analysis, Victorian age, linguistic functional analysis

\section{Introduction}

Jaques Derrida comments upon the language that "our experience of ourselves and our world is produced by the language we speak." (Tayson, 2006, p. 257), intending that language constructs the human experience rather than being the product of experience, and creates the conceptual framework for ones' experience. In other words, language is our "ground of being", a carrier to generate and preserve knowledge in the world. Rather, the language plays a cardinal role in constructing human social ideology and forms human consciousness, explaining that all human attitudes, beliefs, customs, values and identities are shaped by a language. So, it can be convincingly deduced that a human being is indubitably the construct of language that, first, invents ones' consciousness then it internalizes the dominant ideology of society into the person as a social behavior. Apart from the language as a social semiotic behavior, Critical Discourse Analysis seems amenable to be utilized as the most appropriate method to encompass not only social ideologies but also elucidates how language is resorted to control the mind and inwardly manipulate the power in order to attain the personal gains. As Van Dijk defines critical discourse analysis that it is a type of discourse analytical research that primarily studies the way social power abuses, dominance and inequality are enacted, reproduced, and resisted by text and talk in the social political context. Therefore, the present research has been carried out to present the extensive and exhaustive analysis of Victorian ere by examining a short "The Duchess and the Jeweller" written by Virginia Woolf. 
For this purpose, critical discourse analysis method has been applied to the stream of consciousness narration technique of the short story by rendering Systemic Functional Grammar and Lacanian psychoanalysis so that stylistic, syntactical and psychological analyses of the protagonist of the short story. It aims to prove Oliver (the protagonist) as the typical representative of socio-cultural perspective of Victorian age. Hence, the conclusion need to be drawn that the discourse analytical research explicitly illustrates the social problems, power relations and ideological before the readers, to understand the significance of language at micro and macro level. Before embarking upon human ideology, it is primarily imperative to analyze the human conscious; therefore, stream of consciousness is considered as one of the best psychological techniques to represent human consciousness. Virginia Woolf comments upon prose writing in her essay, "Modern Fiction, "let us record the atoms as they fall on the mind in order in which they fall, let us trace the pattern, however disconnected and incoherent in appearance."

Virginia's suggested that for writing modern fiction, meanings, that all the thoughts that are created in mind, should be written in the same sequence as they are created in spite of their disunity and unintelligibility. Virginia Woolf (1924) argues in her essay, "Mr. and Mrs. Brown" that one needs to pay attention to the full complexity and incoherence of inner life so that a flesh and blood can be created. It means that it is imperative to unveil the human's interior life in order to understand one's personality. Peter Childs and Roger Fowler (1973) define, "Stream of Consciousness", "A technique which seeks to record the flow of impressions passing through a character's mind." (Childs. P \& Fowler. R, 1973, p. 224). In other words, the prime purpose of stream of consciousness is to embody the human experience. In this short story, "The Duchess and Jeweler", Virginia Woolf has utilized stream of consciousness to reveal the experience of Oliver from his childhood as a poor boy to young man, from being a thief to the richest jeweler, and his efforts to achieve the social respectability; moreover, his internal conflict regarding giving a handsome amount for purchasing the false pearls by the Duchess for the sake of acquiring social respectability can be presented before readers. It manifests hypocrisy and materialistic approach of the Victorian society. Furthermore, the philosopher of mind Denial Dennett (1983) remarked on consciousness, "human self is nothing more or less than the 'center of narrative gravity' within the brain.' It means that human being can be called nothing else than the collection of stories in the human mind. (Bates. J, 2010, p.138). In profound sense, the tales that are made in our mind develop one's character or personality or it can be interpreted that the human experience is a source for the production of human consciousness and narrative selfhood. (Bates. J, 2010, p.138). Virginia Woolf, through the psychological representation of Oliver, expounded her opinion about the understanding of character's inner life without which, it cannot be explored fully.

In addition, Systemic Functional Grammar's transitivity system analysis showed that what types of processes have been construed to portray the protagonist's internal and external experience. It was grammatically elucidated with doing, sensing, saying, being and having. The material processes revealed what kind of apparently physical actions were performed, the mental processes unveiled the internal world of the mind, the relational processes, demonstrated the existence of relationship, the verbal processes explained what is said or can be the verbs of saying; behavioral processes explain psychological, physiological behavior, and the existential processes presented the existence of something. It means that transitivity system gives us the full analysis of human experience and contextual background. Therefore, Systemic functional Grammar has been utilized to analyze the stream of consciousness text so that the stylistic perspective of stream of consciousness might likely be not understood and examined closely. Hence, the transitivity system of Systemic function Grammar and Lacanian psychoanalysis can be deemed as the best tools to explain, firstly, how the stream of consciousness as a syntactical style and, secondly, its psychological perspective in delineation of characters in the story.

As far as the Lacanian psychoanalysis, the focus of Lacanian criticism is principally on the relationship between the reader and text not upon unconscious of character or the author as he himself states that unconsciousness is structured liked language. It intends that when an infant starts to acquire language, its concepts about the society and itself develops, so the infant's thoughts, in this way, are influenced by the societal ideology. Moreover, the language makes us the subject of society and its slaves. Therefore, the Lacanian psychoanalysis has been applied to the short story "The Jeweler and The Duchess" to give us the insights into the protagonist's consciousness that is created and influenced by the Victorian ideology, and it impels him to manipulate every evil action to be the part of Victorian elite. Therefore, it can be said that the Lacanian psychoanalysis surely explains the role of language in human being and how it constructs his or her ideology. 


\subsection{Research Questions}

1. How hidden ideologies are embodied by Virginia Woolf in the story, "The Duchess and the Jeweler"?

2. How discursive strategies are used by writer to highlight the reality behind social status of Oliver Bacon?

This study is based on the assumption that language construes the human consciousness that is influenced by the social order. Transitivity system of Systemic Functional Grammar and Lacanian Psychoanalysis give the detailed analysis of Oliver Bacon's thoughts, who is the epitome of the Victorian society. He perpetrated corrupt doings to gain the social respectability so that he might be socially accepted specifically by the upper class. In this respect, the following points proved the thesis statement and provide answers to the research question:

1. First, the writer has used projection to form the stream of consciousness text so that the omniscient writer's narration can be reduced to minimum. At the level of projection, the content of a 'verbal' clause of saying is exploited, resultantly, the exact words of the main character can be presented. Rather, the mood of locution projection is quote, meaning that the nexus of verbal process as the level of projection and paratactic as the mood of projection are mostly unveiled by the insights of the Oliver (the protagonist) in order to record or capture the thoughts of Oliver's consciousness. So, it can be ascertained that Virginia Woolf, has deliberately used main character's locution paratactic projection to unveil true representation of his character.

2. The highest concentration of material processes among the other ideational processes highlight Oliver's corrupt action in order to expose Victorian society ails that is hypocritical, materialistic and corruption because he adopted corrupt practices to become the richest jeweler; then he intentionally became victim by paying handsome amount for the fake pearls to become a part and parcel of status quo of fake Victorian nobility.

3. The psychoanalysis Oliver's ideology (Symbolic Order) based on Lacanian theory, further endorsed the social order of Victorian society that a person in spite of being corrupt and hypocrite can be regarded as respectable if one is affluent and wealthy. It might be inferred that Symbolic Order comprises society's ideologies, its beliefs and its values. Victorian society shapes the ideology of Oliver that creates his personality. Hence, it can be cogently inferred that Oliver as a product of society so that he could be recognized as the part of patrician society rather than being considered as member of plebian society.

\section{Conclusion}

Critical Discourse Analysis was applied to "The Jeweler and the Duchess" to demonstrate the hidden ideologies of Victorian society by rendering Transitivity System of Systemic Functional Grammar and Lacanian Psychoanalysis. This study supports that language and society constructs human personality. Further, the Transitivity System unveils the experience of the main participant, Oliver Bacon, and, on the other hand, Lacanian Psychoanalysis elucidates how the unconsciousness of Oliver in the background influences his consciousness. Basically, both these theories are complement to each other on the bases of the similar point related to the key role of language in the human life. Moreover, Critical Discourse Analysis of the text "The Jeweler and the Duchess" likewise reveals Virginia Woolf's ideology about the most microscopic nuances of class distinction that reflects hypocritical and corrupt Victorian society. In conclude, this study will definitely assist the English Language Learners to understand complex writings of stream of consciousness text and, furthermore, it will also guide them to analyze the modern novels and their writers.

\section{References}

Barry, P. (2002). Beginning theory. Wales: Manchester.

Bate, J. (2010). English Literature: A Very Short Introduction. New Yorl: Oxford university Press.

Fowler., P. C. (2006). A Dictionary of Modern Critical Terms. In P. C. Fowler., A Dictionary of Modern Critical Terms (pp. 224-226). New York: Routledge.

Halliday, M. (2014). Halliday's Introduction to Functional Grammar. In H. I. Grammar, M.A.K. Halliday (pp. 212-348). New York: Routledge.

Nayar, P. K. (2009). A Short History of English Literature . Dehli: Cambridge University Press India.

Singh, T. (2013). A History Of English Literature. Dehli: Student Store .

Tayson, L. .. (2006). Criticl Theory Today. New York: Routledge.

Woolf, V. (2018, December Sunday). JThe Duchess and the Jeweler - Vita Education Services. Retrieved from www.vitaeducation.org/wp.../Woolf-Virginia-The-Duchess-and-the-Jeweller.pdf: wwe.google.com.pk 